\title{
Increase in Apoptosis and of the Stress Protein HSP70 in the Mouse Epididymis Produced by the Antiandrogen Flutamide
}

\author{
El Antiandrógeno Flutamida Produce un Aumento de la Apoptosis \\ y de la Proteína de Stress HSP70 en el Epidídimo del Ratón
}

*Eduardo Bustos Obregón \& ** Pedro Esponda

BUSTOS-OBREGÓN, E. \& ESPONDA, P. Increase in apoptosis and of the stress protein HSP70 in the mouse epididymis produced by the antiandrogen Flutamide. Int. J. Morphol., 27(2):463-468, 2009.

SUMMARY: The general aim of this paper was to characterize some changes induced by androgen receptors blockage in the epithelial cells of the mouse epididymis. The antiandrogen flutamide was injected $(10 \mathrm{mg} / \mathrm{Kg} \mathrm{b}$.w. $)$ to adult male mice which were sacrificed 24h. and 72h. after. Controls injected with the vehicle (corn oil) were sacrificed at the same intervals. Cryosections were made of the epididymides and examined by the TUNEL method for quantification of apoptosis and also using immunocytochemistry to visualize the expression of the stress protein HSP70. The highest indexes of apoptosis were observed in the caput epididymis after $72 \mathrm{~h}$. and were of 7.40 cells $/ 1000$ in contrast to controls $(0.21$ cells/1000). HSP70 appeared particularly increased in the caput and cauda epididymis after $72 \mathrm{~h}$. treatment. Results indicated that the blockage of androgen receptors induces apoptosis and a HSP70 expression in the principal epithelial cells of the mouse epididymis, and that these changes occur in a region-specific fashion.

KEY WORDS: Antiandrogen; Apoptosis; Epididymis; Flutamide; Stress proteins.

\section{INTRODUCTION}

The epididymis is a regionalized organ which posses an important role in mammalian reproduction (Cooper, 1986). The different epididymal regions ensure sperm concentration, maturation, transport and storage. Sperm maturation occurs principally in the proximal (caput) region, meanwhile the distal (cauda) region serves as an sperm storage (Cooper). The epididymis, as the whole genital tract, is controlled by androgens. Androgen withdrawal induces serious changes in the morphology and physiology of the epididymis, regulating gene expression, protein secretion, cell survival, etc. (Cooper; Esponda \& Bedford, 1986; Hinton et al., 1998). The non-steroidal compound Flutamide (Brogden \& Clissold, 1989; Viguier-Martínez et al., 1983) is capable to block the androgen receptors. The association of Flutamide to the androgen receptors produces an inactivation of these receptors and its effects have been analyzed in several occasions (Brogden \& Clissold; ViguierMartínez et al.).
Apoptosis is defined as a set of morphological and biochemical changes at different cellular levels. Apoptosis results in a programmed cell death that causes the elimination of unwanted cells (Wyllie et al., 1980). The phenomenon of apoptosis in the epididymis has been scarcely studied (Fan \& Robaire, 1998; Jara et al., 2002; 2004). It has been shown that androgen withdrawal produced by orchidectomy induces apoptosis in the epididymal principal cells (Fan \& Robaire). A notorious increase in apoptosis has been observed when the temperature of the cauda epididymis is increased in $5-7^{\circ} \mathrm{C}$ using a surgical procedure (Esponda \& Bedford). Ageing has also been reported as other cause of apoptosis in the epididymis as demonstrated in the mouse (Jara et al., 2004) and in the rodent Octodon degus (Bustos-Obregón \& Esponda, 2004). In the case of the aged epididymis the apoptotic changes observed were related to a fall in testosterone and a discrete decrease in androgen receptors (Jara et al., 2004). Furthermore, recent experiments demonstrated that a

\footnotetext{
* Universidad de Chile, Medical School. ICBM. Santiago, Chile

** Centro de Investigaciones Biológicas. CSIC. Madrid, Spain.

This work was partially supported by grant BCM2003-00211 from DGICYT (Spain).
} 
photoperiod-induced apoptosis occurs in the epididymis of the golden hamster (Carballada et al., 2007).

Heat Shock Proteins (HSPs) or Stress Proteins have been amply analysed in the last years. HSP and particularly HSP70 functions as molecular chaperones, induces folding and transport of some proteins, and they also protect cells of stress or nocive conditions (Georgopoulos \& Welch, 1993). HSP have been related to the apoptotic phenomenon (Beere \& Green, 2001) as molecules which increase resistance to apoptosis in different cell and tissues (Samali \& Cotter, 2006).

In the present paper we analyzed the changes induced by the anti-androgen Flutamide in the epithelium of the mouse epididymis. We particularly analyzed changes in the apoptotic indexes and the presence of the stress protein HSP70 in the epididymal epithelial cells.

\section{MATERIAL AND METHOD}

Adult male mouse of the Swiss strain were employed. Animals were housed at constant temperature in a $12 \mathrm{~L}: 12$ D cycle with food and water ad libitum. Flutamide (Tecnofarma S.A. Santiago, Chile) was prepared at a concentration of $50 \mathrm{mg} / \mathrm{ml}$ in sterile corn oil (Mazola R. Chile). Twelve male mice were intraperitoneally injected with $200 \mu \mathrm{l}$ of the solution of flutamide delivering $10 \mathrm{mg}$ per $\mathrm{Kg}$. of body weight. Control animals were eight mice injected with $200 \mu \mathrm{l}$ of corn oil. Animals were killed 24 or 72 hours after injection and the epididymis was removed. Animals were killed using ether anesthesia and the protocol used was covered by the law 223/88 on Animal Protection of Spain, and the European Agreement about Vertebrate Animal Protection (3/18/1986) and has been approved by the CSIC Ethical Committee.

The epididymides were isolated and dissected free of fat. For fixation, pieces of the caput, corpus and cauda epididymis were immersed in $2 \%$ paraformaldehyde in phosphate-buffered saline (PBS) at $\mathrm{pH} 7.2$ and kept for 1-4 hours at $4^{\circ} \mathrm{C}$. Samples were exhaustively washed and used for cryosections. A Leica CM-1800 Cryostat was employed and sections of 5-10 $\mu \mathrm{m}$ were mounted on polylysine-coated slides.

For detection of DNA fragmentation in situ we employed the TUNEL (Terminal transferase dUTP nick-end labelling) procedure. The TUNEL kit was from Roche (Indianapolis. IN. USA) and was used following manufacturer instructions. After staining, slides were covered using a PBS solution containing $0.1 \%$ Vectashield (Vector
Labs., Burlingame. Illinois) to prevent the quenching of fluorescence, and 10mM Hoechst 33342 (Sigma, St. Louis, MO) for DNA stain. For detection of HSP70 an immunochemical procedure was employed. Cryostat sections from fixed samples were blocked by incubation in $1 \% \mathrm{BSA}$ in PBS. The primary antibody was anti-HSP70 from Amersham (Amersham Biosc. Ltd. Buckinghamshire, England) and was employed overnight at $4^{\circ} \mathrm{C}$ at a concentration of $2 \mu \mathrm{g} / \mathrm{ml}$. After washings, an anti-mouse IgG conjugated to FITC, diluted to 1:500 in PBS was employed during 1 hour at room temperature as the secondary antibody. After washings, slides were covered with the Vectashield/ Hoechst solution. In all cases controls were used and they were tissues treated only with corn oil or tissues which were treated only with buffer, or in the case of immunocytochemistry, omitting the primary or both antibodies. Positive reactions of cells from TUNEL or from HSP70 immunocytochemistry were observed under fluorescence. Images were captured using a microscope equipped with a CCD System (200A, Polytronics, Emsworth, England). A BioRad MRC-600 Laser Confocal microscopy was also employed.

The number of apoptotic cells was determined counting randomly selected areas of the sections. A minimun of 10 sections and 5000 epididymal epithelial cells per animal were counted. In the case of HSP70 the same method was used and a minimun of 1000 epithelial cells per animal were analyzed. In both cases, Hoescht staining indicates the total number of nuclei and then the cell number to be compared with the positively fluorescent TUNEL or HSP70 cells. The number of apoptotic cells were expressed x 1000 and in the case of HSP70 x100.

\section{RESULTS}

TUNEL method. Apoptotic cells were localized in the different regions of the epididymis of control animals but in very low percentages (0.21-0.38/ 1000) (see Table I). These percentages were notably increased after the treatment with Flutamide and particularly after 72hours (2.76-7.40/ 1000). In some cases tissues treated during 24 hours show none or very low degree of changes (see Table I and Fig. $1 \mathrm{a}, \mathrm{b}$ ) The most affected regions in the epididymis were the caput and the cauda (Figs. $1 \mathrm{c}-\mathrm{f}$ ). The corpus showed the lower apoptotic indexes (see Table I). The total number of apoptotic cells appeared in the epithelium and they are undoubtedly principal cells. Typical apoptotic bodies containing condensed and desorganized chromatin were observed in the epithelium of the 72 hours treated animals (Fig 1.g). Control preparations did not show fluorescence in the epithelial cells. 

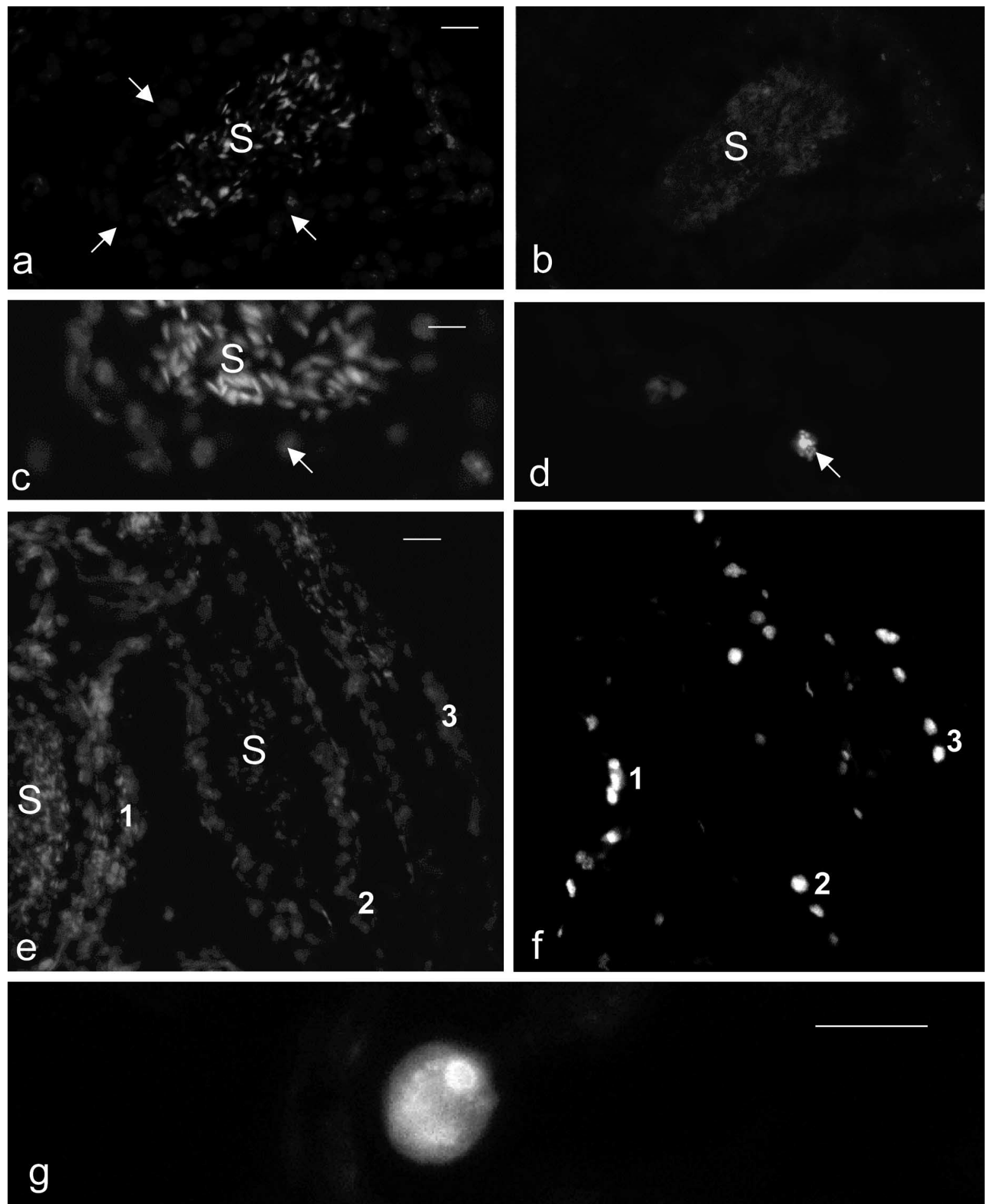

Fig. 1. Flutamide experiments and TUNEL method. a) and b) Caput epididymis of an animal injected during 24 hours. In a) After Hoechst staining the nuclei of the epithelial cells (arrows) and those of spermatozoa (S) are fluorescent. b) After TUNEL reaction no positive cells appear in the epithelium. The bar: $20 \mu \mathrm{m}$. c and d) Caput epididymis from a $24 \mathrm{~h}$. treated animal. In c) after Hoechst staining. In d) After TUNEL. Some nuclei are positive. One of them is indicated in both pictures (arrows). S: Spermatozoa. The bar: $10 \mu \mathrm{m}$. e and f) Cauda epididymis from a $72 \mathrm{~h}$. treated animal. In e) Hoechst staining showing the nuclei from epithelial cells and spermatozoa (S). In f) after TUNEL method several nuclei from epithelial cells appeared fluorescent. Numbers 1, 2 and 3 indicate the same regions of the epithelium in both pictures. The bar: $20 \mu \mathrm{m} . \mathrm{g}$ ) Cauda epididymis from a 72 treated animal. A typical apoptotic nuclei showing a striking fluorescence after TUNEL procedure. The bar: $20 \mu$. 
Table I. Apoptotic cells determined by TUNEL method and presence of HSP70 in the different epididymal regions.

\begin{tabular}{lccc}
\hline Epididymal Regions & Controls & Flutamide 24 hours & Flutamide 72 hours \\
\hline Apoptosis (positive cells x 1000) & & & \\
Caput & 0.21 & 0.85 & 7.40 \\
Corpus & 0.29 & 1.05 & 2.76 \\
Cauda & 0.38 & 1.52 & 4.70 \\
HSP70 (positive cells x100) & & & \\
Caput & 1.80 & 2.0 & 28.8 \\
Corpus & 0.90 & 1.6 & 13.6 \\
Cauda & 2.70 & 5.9 & 30.7 \\
\hline
\end{tabular}
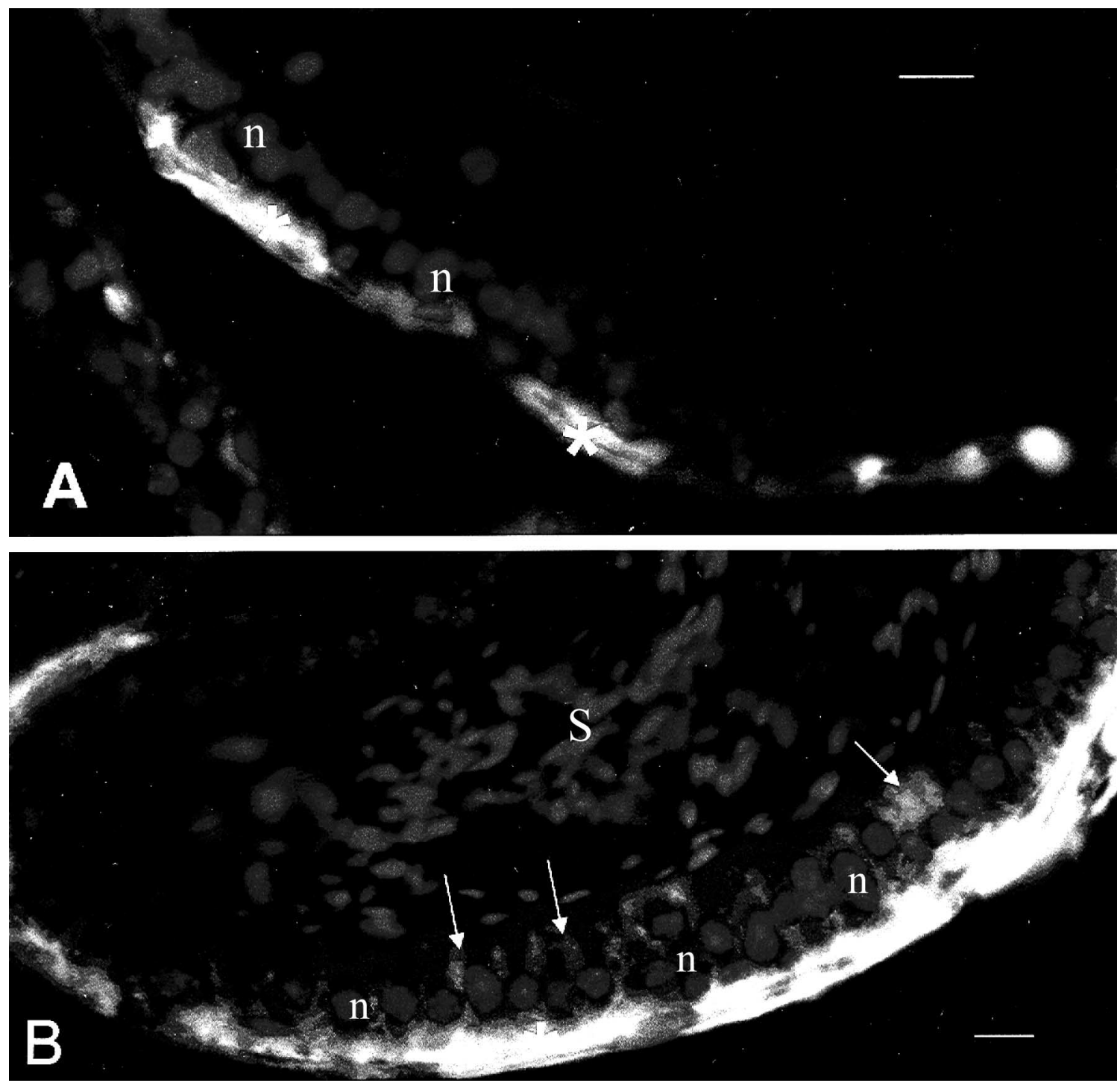

Fig. 2. Cauda epididymis after Flutamide treatment and immunocytochemistry for HSP70. These samples were photographed with filters for Hoechst (nuclei) staining and green filters for localisation of antibody fluorecense. This is a confocal image showing both types of fluorescence. A) After 24 hours treatment there is not posive fluorescence in the epithelial cells cytoplasm. A non-specific positive fluorescence occurred in the basal lamina (*). (n) Show some nuclei from epithelial cells. B) After $72 \mathrm{~h}$. treatment some fluorescence appears in the cytoplasm of epithelial cells (arrows). The intense nonspecific fluorescence can be seen in the basal lamina. Some nuclei of the epithelium are indicated (n). The bars: $10 \mu \mathrm{m}$. 
Localization of HSP70. Tissues from animals treated with Flutamide during 24 hours show a low positive reaction (1.6$5.9 \%$ ) in the cytoplasm of the principal cells (Fig. 2. A and Table I). Nevertheless, in epididymides treated during 72 hours a positive fluorescence occurred in the cytoplasm of some epithelial cells. The higher percentages were observed in the caput epididymis (28.8\%) and in the cauda (30.7\%). Positive cells showed a diffuse green fluorescence surrounding the nucleus (Fig 2 B). Furthermore, the treated epididymis as well as the controls showed a fluorescent non-specific reaction at the level of the lamina propria (Fig. 2 B). Control preparations in which only the second antibody (FITC labelled) was employed showed a similar non-specific fluorescence in the lamina propria. Control preparations in which the two antibodies were omitted did not show fluorescence.

\section{DISCUSSION}

Results clearly show that Flutamide treatment induced apoptotic cells and the Stress Protein HSP70 in the principal epithelial cells of the mouse epididymis. The blockage of androgen receptors undoubtedly changes the androgen metabolism of principal cells and the homeostasis of the epithelium (Brinkmann et al., 1999). As a response they increase their apoptotic index and as a consecuence HSP70 appear in the cytoplasm. The caput and the cauda epididymis are particularly affected by Flutamide, meanwhile the corpus epididymis show a low number of apoptotic cells.

Changes in the epididymis are not surprising since this organ depends on androgen and testicular factors (Cooper; Esponda \& Bedford; Hinton et al.). Experiments using castrated rats showed that the different epididymal regions showed different apoptotic indexes (Fan \& Robaire) as we described in this paper. This analysis after castration showed that apoptotic cells rapidily appeared in the caput epididymis after $24 \mathrm{~h}$ treatment and some days later they were observed in the corpus and cauda (Fan \& Robaire). The degree of damage in the caput seems to be different because androgen replacement could not prevent apoptosis as occur in other regions (Fan \& Robaire). A similar situation was reported in the epididymis of aged rodents as the mouse (Jara et al., 2002) and in Octodon degus (Bustos-Obregón \& Esponda, 2004) in which the caput was the region which showed higher percentages of apoptosis. All these results demonstrated that there exist a different regional response of the epididymal epithelium faced to the changes occurred in their environement. In this regards, it has been demonstrated that gene expression is differentially regulated in the different epididymal segments (Serre \& Robaire, 1998). In the case of castrations these different responses were supposed to be a reflection of the differences in androgen concentration in the luminal fluids along the epididymis (Fan \& Robaire). Similar suggestions were made for aged mouse because old testes secreted much less testosterone (Jara et al., 2004). It seems important to note that it is known that the corpus epididymis is the most sensible region to the action of androgens (Ezer \& Robaire, 2003; Gooren, 1998). Obviously, changes related to ageing are also closely connected to the fall in androgen occurred in aged males (Jara et al., 2004). In that case, testosterone supplementation was able to suppress the deleterious effects of old age in the male tract of the mouse, and apoptotic indexes become normal after the hormone supplementation (Jara et al., 2004).

Our results show that despite the presence of androgens in the epididymal fluids, testicular factors contained in testicular fluids influence epididymal function. This fact was clearly observed after efferent duct ligation which produces striking changes in the gene expression and survival of the epithelial cells (Hinton et al.; Gooren). Furthermore, there are evidences that these changes are related to other factors than the presence of intraluminal androgens (Hermo et al., 2000). Our results clearly show that the role of androgen receptors is important for the maintenance of the normal phisyological conditions of the epithelial cells of the duct.

The blockage of androgens receptors by Flutamide also produces an increase in the protein HSP70 in the epithelial cells of the mouse epididymis. The increase of this HSP show a close relation to the apoptotic indexes (see Table I). Then, HSP70 seems to be the response of the principal cells to metabolic and apoptotic changes induced by the lack of androgens in their cytoplasm. The relation of HSPs with apoptosis has been commented (Beere \& Green). In cell cultures, it was shown that heat shock proteins increase resistance to apoptosis (Lan et al., 1998). It is possible that in an androgen depending organ, as the epididymis, back of androgenic activity elicits a stress resulting in over expression of HSP70. As commented in the case of the senile mouse (Jara et al., 2004), this over expression would be not sufficient to counteract the apoptosis of the epididymal epithelial cells. In several cases it has been shown that apoptotic increase is correlated to the presence of HSP70, as occurs after castration in the prostate or in the cryptorchid testes (Guo et al., 2001). Recent analyses on the human cryptorchidism showed that HSP70 expression and mRNA are higher in the corpus and cauda epididymis (Legare et al., 2004). In the rodent Octodon degus it was observed that HSP70 appeared notably increased in the cauda epididymis of aged animals (Carballada et al.). As for the case of apoptosis, the occurrence of HSP70 seems to be also a region-specific phenomenon. 
BUSTOS-OBREGÓN, E. \& ESPONDA, P. El antiandrógeno Flutamida produce un aumento de la apoptosis y de la proteína de stress HSP70 en el epidídimo del ratón. Int. J. Morphol., 27(2):463-468, 2009.

RESUMEN: Este trabajo estudia los cambios inducidos por el bloqueador de receptores de andrógeno flutamida en el epitelio del epidídimo del ratón. Varios machos adultos fueron inyectados con flutamida (10mg/Kg.b.w.) y se sacrificaron a las 24 y $72 \mathrm{horas}$. Otros machos, que sirvieron de controles fueron inyectados sólo con el vehículo empleado para las inyecciones (aceite de maíz) y se sacrificaron a intervalos similares. Los epidídimos tratados y controles fueron examinados mediante el método TUNEL para cuantificar la apoptosis y mediante procedimientos inmunocitoquímicos para localizar la proteína de stress HSP70. El índice apoptótico más alto fue observado en la cabeza del epidídimo después de 72 horas de tratamiento. HSP70 se observó también a las 72 horas en la cabeza y en la cauda epididimaria. Los resultados indican que el bloqueo de los receptores de andrógenos induce apoptosis y expresión de HSP70 en las células principales del epitelio epididimario, y que estos cambios ocurren afectando a regiones específicas del epidídimo.

\section{PALABRAS CLAVE: Antiandrógenos; Apoptosis; Epidídimo; Flutamida; Proteínas de stress.}

\section{REFERENCES}

Beere, H. M. \& Green, D. R. Stress management of heat shock protein-70 and the regulation of apoptosis. Trends Cell. Biol., 11(1):6-10, 2001.

Brinkmann, A. O.; Block, L. J.; De Ruiter, P. E.; Doesburg, P.; Steketee, K.; Berrevoets, C. A. \& Trapman, J. Mechanisms of androgen receptor activation and function. J. Steroid. Biochem. Mol. Biol., 69(1-6):307-13, 1999

Brogden, R. N. \& Clissold, S. P. Flutamide. A preliminary review of its pharmacodynamic and pharmacokinetic properties, and therapeutic efficacy in advanced prostate cancer. Drugs, 38(2):185-203, 1989.

Bustos-Obregón, E. \& Esponda, P. Ageing induces apoptosis and increases HSP70 Stress Protein in the epididymis of Octodon degus. Int. J. Morphol., 22(3):29-34, 2004.

Carballada, C.; Jara, M. \& Esponda, P. Photoperiod-induced apoptosis in the male genital tract epithelia of the golden hamster. Int. J. Androl., 30(2):73-9, 2007.

Cooper, T. G. The Epididymis, Sperm Maturation and Fertilisation. Berlin, Springer Verlag, 1986.

Esponda, P. \& Bedford, J. M. The influence of body temperature and castration on the protein composition of the fluid in the rat cauda epididymis. J. Reprod. Fertil., 78(2):505-14, 1986.

Ezer, N. \& Robaire, B. Gene expression is differentially regulated in the epididymis after orchidectomy. Endocrinology, 144(3):97588,2003

Fan, X. \& Robaire, B. Orchidectomy induces a wave of apoptotic cell death in the epididymis. Endocrinology, 139(4): 2128-36, 1998.

Georgopoulos, C. \& Welch, W. J. Role of the major heat shock proteins as molecular chaperones. Ann. Rev. Cell Biol., 9:601-34, 1993.

Gooren, L. Endocrine aspects of ageing in the male. Molec. Cell. Endocrinol., 145(1-2):153-9, 1998.

Guo, C. X.; Ma, J.; Zhou, X. C. \& Liu, Y. X. Expression of HSP70-2 gene during germ cell apoptosis in rat unilateral cryptorchid testes. Arch. Androl., 46(2):109-15, 2001.
Hermo, L.; Xiaohong, S. \& Morales, C. Circulating and luminal testicular factors affected LPR-2 and Apo J expression in the epididymis following efferent duct legation. J. Androl., 21(1):12244,2000

Hinton, B. T.; Lan, Z. J.; Rudolp, D. B.; Labus, J. C. \& Lye, R. J. Testicular regulation of epididymal gene expression. J. Reprod. Fertil., 53:47-57, 1998.

Jara, M.; Esponda, P. \& Carballada, R. Abdominal temperature induces region specific p-53-Independent apoptosis in the cauda epididimis of the mouse. Biol. Reprod., 67(4):1189-96, 2002.

Jara, M.; Carballada, R. \& Esponda, P. Age-induced apoptosis in the male genital tract of the mouse. Reproduction, 127(3):359-66, 2004.

Lan, Z. J.; Labus, J. C. \& Hinton, B. T. Regulation of gamma-glutamyl transpeptidase catalytic activity and protein level in the initial segment of the rat epididymis by testicular factors: role of basic fibroblast growth factor. Biol. Reprod., 58(1):197-206, 1998.

Legare, C.; Thabet, M. \& Sullivan, R. Expression of heat shock protein in normal and cryptorchid human excurrent duct. Mol. Hum. Reprod., 10(3):197-202, 2004.

Samali, A. \& Cotter, T. G. Heath shock proteins increase resistance to apoptosis. Exp. Cell. Res., 223(1):163-70, 2006.

Serre, V. \& Robaire, B. Segment specific morphological changes in aging Brown Norway rat epididymis. Biol. Reprod., 58(2):497513,1998 .

Viguier-Martinez, M. C.; Hochereau de Reviers, M. T.; Barenton, B. \& Perreau, C. Endocrinological and histological changes induced by flutamide treatment on the hypothalamo-hypophysisl testicular axis of the adult male on fertiliy. Acta Endocrinol., 104(2):24652,1983

Wyllie, A. H.; Kerr, F. \& Currie, A. R. Cell death: the significance of apoptosis. Int. Rev. Cytol., 68:251-306, 1980.

Correspondence to:

Prof. Dr. Pedro Esponda

Centro de Investigaciones Biológicas. CSIC.

Ramiro de Maeztu 9

28040 Madrid -ESPAÑA

Email: esponda@cib.csic.es

Received: 22-02-2009

Accepted: 14-03-2009 